\title{
Makna Epitap Kuburan Ki Ageng Kebokenongo Di Situs Pengging Dalam Manfaat Ilmu Pemerintahan
}

\section{Abdul Choliq Nawawi}

Keywords: tomb, inscription, arabic, description, epitaph

\section{How to Cite:}

Nawawi, A. C. (1998). Makna Epitap Kuburan Ki Ageng Kebokenongo Di Situs Pengging Dalam Manfaat Ilmu Pemerintahan. Berkala Arkeologi, 18(1), 53-64. https://doi.org/10.30883/jba.v18i1.776

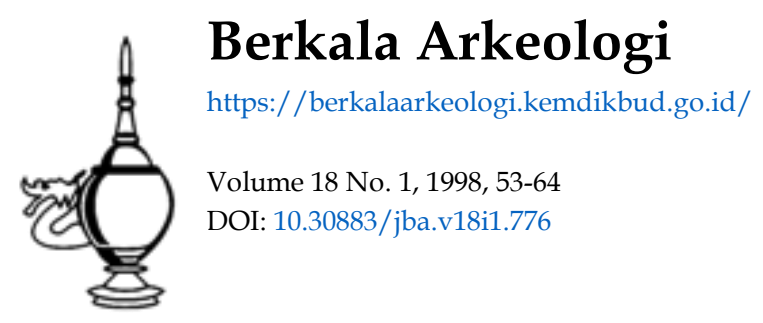

\section{c) (7) (2)}

This work is licensed under a Creative Commons Attribution-NonCommercial-ShareAlike 4.0 International License. 


\title{
MAKNA EPITAP KUBURAN KI AGENG KEBOKENONGO DI SITUS PENGGING DALAM MANFAAT ILMU PEMERINTAHAN
}

\author{
Abdul Choliq Nawawi
}

Pemerintah atau pemerintahan dalam arti sempit adalah pemegang kekuasaan eksekutif, sedangkan dalam arti luas, seluruh lembaga dan kegiatannya dalam suatu negara, termasuk kekuasaan legislatif dan Yudikatif. Pembagian bentuk-bentuk pemerintahan menurut Aristoteles (384-322 s.M) adalah :

1. Monarki, yaitu suatu bentuk pemerintah yang menegaskan bahwa kekuasaan negara berada di tangan seorang penguasa, yang menjalankan kekuasaan itu untuk kepentingan semua orang.

2. Tirani, yaitu suatu bentuk pemerintah yang menegaskan bahwa kekuasaan negara berada di tangan seorang penguasa, yang menjalankan kekuasaan itu untuk kepentingan sendiri.

3. Aristokrasi, yaitu suatu bentuk pemerintah yang menegaskan bahwa kekuasaan negara berada di tangan sejumlah kecil rakyat yang merupakan orang-orang terbaik --yang biasanya dikuasai oleh kaum bangsawan-- dan menjalankan kekuasaannya itu untuk kepentingan semua orang.

4. Oligarki, yaitu suatu bentuk pemerintahan yang menegaskan bahwa kekuasaan negara berada di tangan sejumlah kecil rakyatnya, yang menjalankan kekuasaannya itu untuk kepentingan sendiri. Dalam bentuk seperti ini biasanya yang memegang kekuasaan adalah kaum pedagang atau golongan rakyat biasa.

5. Demokrasi, yaitu suatu bentuk pemerintah yang menegaskan bahwa kekuasaan negara berada di tangan sejumlah besar rakyat, yang menjalankan kekuasaannya itu untuk kepentingan semua orang.

6. Anarki, yaitu suatu bentuk pemerintah yang kekuasaan negara dipegang oleh sejumlah besar rakyat, tetapi tidak berhasil menjalankan kekuasaan negara untuk kepentingan semua orang. Bentuk pemerintah anarkis umumnya menimbulkan bencana, karena orang dapat melakukan tindakan sewenag-wenang serta melakukan penindasan atas golongan minoritas atau golongan masyarakat yang tidak menyetujui kebijaksanaan pemerintahan atau golongan penguasa. (Dwi Purwoko, 1990: 331-332).

Sementara itu, terbentuknya pemerintahan dalam suatu negara harus memenuhi syaratsyarat yang meliputi:

1. memiliki luas wilayah tertentu yang menjadi kekuasaan pemerintahannya.

2. ada rakyat yang tunduk pada peraturan dan kekuasaan pemerintahannya. 
3. memiliki lembaga-lembaga dan organisasi pemerintahan (Baker, 1829: 127-131).

Pada akhir abad ke-17 M., Montesquieu mengemukakan sebuah gagasan tentang 'Trias Politika'. Trias Politika dapat diartikan sebagai 'tiga pemerintahan' atau 'tiga kekuasaan". yang terdiri dari: "Yudikatif, legislatif dan eksekutif". Ia menafsirkan 'judiciaire' sebagai peradilan terhadap yang melanggar undang-undang, "legislatif" sebagai pembuat undang-undang dan 'eksekutif' sebagai pelaksana undang-undang (Bayu Suryaningrat, 1980: 18).

Pelaksanaan jabatan-jabatan pada Trias Politika itu menurut Montesquieu, terletak pada asas Separation des Pouvoirs. Yang dimaksud Separation des Pouvoirs adalah asas pemisahan kekuasaan. Misalnya: jabatan kepala negara (=eksekutif) tidak boleh dirangkap oleh anggota DPR/MPR (=legislatif). Jadi harus ada incompatibilite constitutionale, yaitu jabatan-jabatan pada saat yang sama tidak boleh dirangkap olch satu orang (Pratomo, 1954: 8-9). Pemerintahan seperti yang diuraikan itu, tampaknya dapat dilihat pada epitap yang terdapat pada kuburan Ki Ageng Kebokenongo di Situs Pengging.

\section{Latar Belakang Permasalahan}

Situs Pengging terletak di Dusun Pengging, Desa Dukuh, Kecamatan Banyudono, Kabupaten Boyolali, Propinsi Jawa Tengah. Jika diukur dari permukaan laut, ketinggiannya mencapai 177 meter. Letak astronomisnya adalah 4²'13" Bujur Timur dan 7 13'39" Lintang Selatan, meridian Jakarta (Abdul Choliq Nawawi, 1990: 1).

Nama Pengging selain tercantum dalam cptap (Epithaphium (bahasa Latin) $=$ prasasti pada batu nisan untuk mengenang orang yang dikubur di situ; suatu pernyataan pendek pada sebuah monumen), juga sering disebut-sebut dalam beberapa naskah kuna, seperti: Nagarakertagama pupuh XVII, bait 6 dan 10 tertulis dengan istilah "Pöngging" (Slametmulyana, 1979: 282-283). Dalam Babad Majapahit-Pajang pupuh 571, bait 20, dinyatakan bahwa Bahureksa (si buaya putih) adalah embah buyut Jaka Tingkir, sebab Bahureksa berputera Jaka Sengara dan Jaka Sengara adalah ayahanda Kebokenongo dari Pengging (Enny Mulyantari, 1988: 464), Babad Jaka Tingkir Pajang (Babad Pajang) menyebutkan adanya kerajaan dan Adipati Pengging (Moeljonosastronaryotomo, 1981: 11-13). Sedangkan di dalam Babad Demak I, pupuh LVIII, lagu Sinom, diberitakan bahwa menantu Prabu Brawijaya di Pengging adalah Adipati Dayaningrat (Slamet Riyadi, 1981: 17-18) serta Babad Tanah Jawi memberitakan adanya Ki Ageng di Pengging (Sudibjo, 1980: 48-49). 
Sumber berita Cina menyatakan bahwa tentara Dji Pang Kang diserang tentara Peng King Kang. Dji Pang Kang wafat, Peng King Kang mendirikan kerajaan Islam di pedalaman jauh dari laut dan tidak memerlukan kapal-kapal. Dji Pang Kang --"Kang" di dalam bahasa Cina dialek Yunan artinya "gubernur"-- adalah Ario Pinangsang yang ayahnya mati dibunuh Sunan Prawoto. Peng King Kang adalah Jaka Tingkir putera Ki ageng Pengging (Ki Ageng Kebokenongo) yang dihukum mati oleh Sultan Tranggana. Teknis pelaksanaan diserahkan kepada Sunan Kudus pada tahun 1527 M.. Setelah selesai peperangan, maka Peng King Kang merupakan sebuah pemerintahan PajangPengging (Graff, et.al., 1984:257). Sampai sekarang di sekitar situs ini masih dapat ditemukan data toponemik, yaitu Dusun Pengging.

Epitap di Situs Pengging ini terukir pada sebuah papan kayu jati, terletak di atas ambang pintu masuk cungkup kuburan Ki Ageng Kebokenongo di dusun Gedong, desa Dukuh, Kecamatan Banyudono. Epitap ini berbahasa dan berhuruf Arab dengan khat gaya Tsuluts, terdiri atas satu baris saja. Keadaan huruf-hurufnya masih baik, kecuali hanya sepatah kata saja yang agak rusak. Pada sisi kanan dan sisi kiri epitap ini ditemukan dua buah gambar lambang matahari yang masing-masing bersinar delapan pancaran dan sering dikatakan sebagai sinar "Surya Majapahit". Jenis angka tahun yang digunakan dalam epitap ini adalah abjad Arab. Informasi yang terdapat dalam epitap ini menyebutkan adanya lembaga-lembaga pemerintahan, seperti: wali, ulama dan syaikh akbar.

Di kompleks kuburan Ki Ageng Kebokenongo ini juga ditemukan sebuah epitap yang ditulis pada sebuah nisan batu. Nisan batu itu merupakan artefak temuan lepas dan epitapnya berbahasa dan berhuruf Arab gaya Naskhi.

\section{Rumusan Masalah}

Dari pernyataan-pernyataan yang telah diuraikan terdahulu, kiranya permasalahan tentang makna epitap kuburan Ki Ageng Kebokenongo di Situs Pengging dalam manfaat Ilmu Pemerintahan, dapat dirumuskan sebagai berikut:

1. Apakah data tekstual pada epitap yang telah mencantumkan nama-nama wali, ulama, dan syaikh akbar itu merupakan unsur-unsur kelembagaan dan keorganisasian dalam ilmu pemerintahan?

2. Bagaimana bentuk pemerintahan yang dianut oleh negara Pengging pada masa lalu?

3. Mengapa bentuk lembaga pemerintahan yang tercantum dalam epitap Ki Ageng Kebokenongo di Situs Pengging itu terdiri atas tiga unsur? Apakah ada nuansa 
kemiripannya dengan konsep Trias Politika dalam mekanisme pemerintahan?

\section{Metode}

Dalam penyelesaian makalah ini, penulis berangkat dari kerangka teori untuk menjelaskan gejala atau kasus tertentu dengan menggunakan metode deduksi (Anonim, 1995: 1). Sedangkan pendekatan yang digunakan adalah pendekatan empatetik (emphatetic approach). Pendekatan ini pada dasarnya mengakui bahwa tindakan manusia dan budaya bendawi yang dihasilkan suatu budaya tertentu tidak selalu bersifat khusus dan unik, tetapi juga mempunyai unsur-unsur yang sama. Namun tidak berarti bahwa generalisasi dan penjelasan silang budaya (cross cultural) dapat diterapkan begitu saja. Cara penjelasan yang disarankan adalah dengan menempatkan diri peneliti menjadi bagian dari budaya yang ditelitinya. Dengan demikian diharapkan peneliti mampu menangkap 'makna' suatu fenomena budaya dalam konteks aslinya yang bersifat khusus. Sebaliknya, ia diharapkan juga bersifat kritis dan dapat menjelaskan fenomena tadi dalam suatu kerangka pikir yang lebih luas (generalisasi / teori). Pendekatan ini diharapkan mampu memberikan pemahaman dan penjelasan yang lebih baik tentang yang ingin dijelaskan (Daud Aris Tanudirjo, 1994: 12; Melas, 1991).

\section{Data dan Pembahasan}

Konsiderans epitap kuburan Ki Ageng Kebokenongo di Situs Pengging ini terbagi menjadi dua bagian kalimat, yaitu muqaddimah (pendahuluan) dan risalah (tugas suei). Susunan kalimat dalam muqaddimah epitap ini menggunakan kalimat thayyibah, yaitu kalimat yang menyatakan tentang ke-Esa-an Allah dan Kerasulan Nabi Muhammad SAW. Bentuk-bentuk hurufnya masih utuh, sehingga mudah dibaca. Transliterasi dan terjemahan muqaddimah epitap ini sebagai berikut:

Transliterasi: La ilaha illallah muhammadur rasulullah.

Terjemahan: Tidak ada Tuhan selain Allah, Muhammad adalah utusan Allah.

Sedangkan susunan kalimat dalam risalah epitap ini ditemukan kata paling awal dan angka abjad untuk nilai ratusannya perlu memperoleh otokritik, karena telah aus. Apabila kurang hati-hati cara membacanya akan menimbulkan salah tafsir, di antara bacaan kata bismika dengan bacaan kata sammaytuka demikian juga dengan abjad dzal $(=700)$ seperti yang sudah terlontar dalam skripsi program studi S-l penulis di Jurusan Arkeologi Fakultas Sastra UGM tahun 1990 dengan angka abjad dlot $(=800)$ hasil otokritik oleh penulis. 
Dalam keadaan biasa, jumlah nibrah (gerigi) rangkaian tulisan bismika banyaknya empat nibrah, yaitu pada hubungan $b a^{\prime}$ dan $s i n$, sedangkan jumlah nibrah rangkaian huruf pada tulisan sammaytuka banyaknya lima nibrah, yaitu pada huruf-huruf $\sin , y a$ ' dan $t a^{\circ}$. Sedangkan angka abjad $d z a l(=700)$ yang terlontar dalam skripsi penulis, disadari, bahwa ketika itu penulis terjebak oleh bentuk huruf $z a i^{\prime}(=7)$ dengan huruf $d z a l(=700)$ seperti yang sudah dibaca penulis dalam data empirik epitap pada waktu itu. Pemakaian angka tahun abjad dlot $(=800)$ dalam penulisan makalah ini, didasarkan atas studi banding pada data tekstual yang tercantum dalam sumber-sumber babad seperti: Babad Tanah Jawi, Babad Jaka Tingkir (Babad Pajang), Babad Demak I dan Babad Majapahit-Pajang.

Di antara kata bismika dan sammaytuka ini yang dapat dijadikan media dasar hukum suatu pernyataan dengan susunan kalimat yang sempurna adalah kata sammaytuka, yang dapat diterjemahkan ke dalam bahasa Indonesia menjadi "saya menamai (mengangkat) anda". Dalam kata sammaytuka terkandung unsur-unsur susunan kalimat sempurna yang terdiri atas subjek, yaitu saya, predikat adalah menamai (mengangkat) dan obyek kalimatnya adalah anda. Pada kata bismika hanya merupakan susunan kalimat tak sempurna (inversi), sebab tidak bersubjek dan diterjemahkan dengan menamai (mengangkat $=$ Jawa : njumenengaken) anda. Sehingga kata bismika ini apabila dipergunakan sebagai pengungkap suatu pernyataan, tidak mempunyai dasar dan subjek hukum. Transliterasi dan terjemahan risalah ini sebagai berikut:

Transliterasi: Sammaytuka waliyyan baynal 'ulama'i bisyaikhil akbari fi baladin Pengging wa hijratun nabiyyi fissanati dlot - nun - wawu.

Terjemahan: Saya menamai (mengangkat) anda selaku wali di antara ulama dengan gelar syaikh akbar di negara Pengging pada tahun hijrah Nabi: 856 .

Secara umum pengertian istilah-istilah: wali, ulama dan syaikh akbar itu sebagai berikut Wali (Arab: wally, jamak: aulia) adalah orang yang memegang suatu wilayah, yakni kekuasaan mengurus urusan, baik urusan umum (pemerintahan) maupun urusan khusus (pribadi dan hartanya). Ulama (jamak dari seorang alim) adalah pengemban tradisi agama Islam dan seorang yang faham akan syari'ah (hukum suci). Kadangkadang juga disebut faqih (ahli hukum Islam), qadli (hakim) dan mufti (penasihat dalam hukum Iślam). Selanjutnya, yang dimaksud dengan istilah syaikh akbar (syaikhul Islam) adalah gelar yang muncul sejak abad ke-2 sampai abad ke-10 hijrah dan diberikan terbatas kepada para pemuka ahli hukum Islam dan tokoh sufi, bila fatwanya mendapat pengakuan mayoritas ulama (Hassan Shadily, 1984: 3404; 3689).

Dari pembahasan data tekstual pada epitap tersebut, dapat diasumsikan bahwa istilah- 
istilah wali, ulama dan syaikh akbar adalah merupakan lembaga dan organisasi pemerintahan. Sedangkan angka abjad tahun: dlot-nun-wawu hijriah $(856 \mathrm{H})$ bertepatan dengan tahun $1452 \mathrm{M}$. Tanggal 1 Muharram $856 \mathrm{H}$ sama dengan tanggal 23 Januari 1452 M (Philips, 1963: 37). Status dan fungsi wali selaku seorang yang melaksanakan kekuasaan pemerintahan di wilayah negara Pengging pada waktu itu, mungkin mirip dengan status dan fungsi lembaga eksekutif dalam konsepsi Trias Politika. Demikian juga status dan fungsi ulama mungkin mirip dengan lembaga legislatif dan syaikh akbar mungkin mirip dengan lembaga Yudikatif.

Luas dan status negara Pengging dalam masa kekuasaan kerajaan Majapahit, tidak lebih dari sebuah desa di bawah kekuasaan kerajaan Majapahit, sebagaimana tercantum dalam Nagarakertagama (Desawamnana), pupuh XVII, bait 10, yang dilindungi oleh peraturan hukum yang berlaku dalam pemerintahan Kerajaan Majapahit. Sementara itu yang dimaksud dengan pengertian 'Desawarnnana' adalah uraian tentang desa-desa (Hasan Djafar, 1978: 9-10).

Peraturan hukum yang berlaku dalam pemerintahan kerajaan Majapahit seperti yang tercantum dalam Nagarakertagama, pupuh LXXXIX, bait 2, berbunyi "Negara dan desa berhubungan rapat seperti singa dan hutan. Jika desa rusak, negara akan kckurangan bahan makanan. Kalau tidak ada tentara, negara lain mudah menyerang kita. Karenanya peliharalah keduanya. Itu perintah baginda". (Lien Dwiari Ratnawati, 1988: 5).

Dengan demikian dapat diasumsikan bahwa Pengging yang tercantum dalam naskah Nagarakertagama, pupuh XVII, bait 6 dan 10, pada tahun Saka Aksatisurya, yaitu tahun 1275 Saka (tahun 1353 M) pernah dikunjungi oleh Sri Nata Wilwatikta adalah memiliki kekuasaan pemerintahan desa seperti yang tercantum dalam Nagarakertagama (Desawarnnana), pupuh XVII, bait 2.

Pada tahun 1353 M Pengging sudah memiliki kekuasaan pemerintahan desa di bawah kekuasaan pemerintahan kerajaan Majapahit, maka pada tahun $856 \mathrm{H}$ (tahun $1452 \mathrm{M}$ ) dengan terbitnya konsiderans (alasan hukum; tujuan hukum dan dasar hukum) pada epitap di kuburan Ki Ageng Kebokenongo di situs Pengging tersebut, secara de facto dan de jure, Pengging adalah salah satu desa di bawah kekuasaan Kerajaan Majapahit, meskipun bersosial budaya Islam. Simbol kekuasaan pemerintahan desa di Pengging yang berwujud gambar dua pancaran sinar matahari, disamping sebagai lambang kebesaran Kerajaan Majapahit, juga merupakan lambang sosial budaya Islam, seperti matahari, bumi, bulan, dan bintang.

Berlakunya lembaga-lembaga pemerintahan yang bercorak budaya Islam yang 
bersumber dari epitap kuburan Ki ageng Kebokenongo di Situs Pengging pada tahun $856 \mathrm{H}$ (tahun $1452 \mathrm{M}$ ) tersebut, paling tidak telah memperoleh legitimasi dari pemerintahan kerajaan Majapahit dengan ketetapan peraturan hukum yang tercantum dalam Nagarakertagama, pupuh XLIII, bait 2, tentang ajaran pancasila, laku utama (Slametmulyana, 1979: 295).

Tentang isi butir-butir Pancasila Krama yang berlaku di wilayah kekuasaan kerajaan Majapahit, Darji Darmodiharjo, menyatakan sebagai berikut :

1. Tidak boleh melakukan kekerasan

2. Tidak boleh mencuri

3. Tidak boleh berjiwa dengki

4. Tidak boleh berbohong

5. Tidak boleh mabuk minuman keras (Lasiyo,et.al., 1985: 1-2)

Kelima butir Pancasila Krama dari Kerajaan Majapahit ini sangat manusiawi, bersifat universal dan dapat diterima oleh setiap orang yang berakal sehat, karena menghargai nilai-nilai moral dan menjunjung tinggi harkat dan martabat kemanusiaan yang adil dan beradab.

Oleh karena itu, bagi penduduk Pengging yang bersosial budaya Islam sekitar tahun 856 H (tahun 1452 M) seluruh butir Pancasila Krama dari Kerajaan Majapahit ini tidak bertentangan dengan pendidikan dan pengamalan akhlaqul karimah (budi pekerti yang mulia), sebagaimana yang telah menjadi ketentuan dan peraturan hukum agama Islam yang bersumber dari Al Qur'an dan Al Hadits, dalam pergaulan antar sesama umat manusia.

Dalam kompleks kuburan Ki Ageng Kebokenongo di Situs Pengging juga masih terdapat sebuah epitap lain yang berbahasa dan berhuruf Arab dengan khat gaya Naskhi, tertulis di atas sebuah nisan batu. Transliterasi dan terjemahan epitap ini sebagai berikut,

Transliterasi: Hadzal qabriy kiyahiy iman bayalaluwiy.

Terjemahan: Ini adalah kuburanku: Kiai Iman Bayalaluwi

Kata baya diserap dari bahasa Sansekerta bhaya yang berarti prajurit (penjaga). Kata laluwi secara ethimologis dapat berasal dari kata lalay (Jawa Kuna), kemudian menjadi lale dalam bahasa Jawa Baru. Kata lalay maupun lale berarti tembok atau benteng (Zoetmulder, 1982: 228; 966). 
Jadi secara mutatis dan mutandis keberadaan Kiai Iman Bayalaluwi selaku salah seorang prajurit benteng pada masa kejayaan Kerajaan Majapahit, berdomisili di negara Pengging pada tahun $1452 \mathrm{M}$ adalah sah menurut ketetapan dan peraturan hukum yang berlaku di wilayah kekuasaan Kerajaan Majapahit, seperti yang tercantum dalam Nagarakertagama, pupuh LXXXIX, bait 2, dinyatakan, bahwa raja Majapahit memerintahkan agar tentara dan negara harus dipelihara.

Dalam naskah Babad Demak I, pupuh LVIII, lagu Sinom, dinyatakan bahwa menantu Prabu Brawijaya di Pengging, Adipati Dayaningrat telah lama meninggal dunia. Ia meninggalkan dua orang anak laki-laki, yaitu Raden Kebokanigoro dan Raden Kebokenongo. Setelah Majapahit jatuh, Raden Kebokenongo berguru kepada Syaikh Sitijenar tentang agama Islam bersama-sama Ki Ageng Tingkir. Orang Pengging akhimya juga memeluk agama Islam semuanya. Raden Kebokenongo kemudian menikah dengan adik Ki Ageng Butuh, sedangkan hubungannya dengan Ki Ageng Tingkir bagaikan dua orang bersaudara (Slametriyadi, et.al., 1981: 105-107). Selanjutnya dalam Babad Demak I, pupuh XXVIII, lagu Asmarandana, menyatakan bahwa Sultan Demak dalam meresmikan penyelesaian bangunan Masjid Agung Kesultanan Demak mengundang para tamu yang terdiri atas aulia (para wali), ulama, para adipati se tanah Jawa beserta para tamu undangan dari negeri atas angin (negara asing) yang ditandai sengkala yang berbunyi : "mestaka gya pinasang = tanggal 12; wus ngadeg = bulan ke-2 (karo; karwa) - sengkalaning: 'Lawang trus gunaning jalma' = 1399 Saka" (Slametriyadi, 1981:90).

Tanggal 12 (dwadaci) pada pertanggalan Hindu - Jawa jatuh pada bagian cuklapaksa (paro terang), bulan ke-2 (karo; karwa; Bhadrawada) tahun 1399 Saka tersebut bertepatan dengan tanggal 31 Agustus 1477 Masehi (Damais, 1951:12-17).

Babad Demak I juga memberitakan, bahwa jatuhnya kekuasaan pemerintahan Kerajaan Majapahit kurang setahun lagi dari peristiwa tersebut di atas, dengan candrasengkala yang berbunyi: "nir ilang kertaning jagad" sama dengan tahun 1400 Saka (Salametriyadi, et.al., 1981:90), sedangkan candrasengkala versi Kerajaan Majapahit berbunyi : "sirna ilang kertaning bhumi" sama dengan tahun 1400 Saka ini bertepatan dengan tahun 1478 Masehi, dan angka tahun yang ditunjukkan oleh kedua candrasengkala ini memang sama, yaitu tahun 1400 Saka atau tahun 1478 Masehi.

Tetapi, apabila direnungkan makna filosofisnya akan kelihatan secara jelas sekali perbedaannya. Candrasengkala versi Kesultanan Demak yang berbunyi : "nir ilang kertaning jagad" memiliki makna bahwa kemakmuran jagad (bumi) di kesultanan Demak tidak hilang atau musnah. Berarti usia harapan hidup bagi kemakmuran Kesultanan Demak masih panjang, sedangkan candrasengkala versi Kerajaan 
Majapahit yang berbunyi : "sirna ilang kertaning bhumi" memiliki makna bahwa kemakmuran bumi di Kerajaan Majapahit sudah hilang sama sekali. Berarti, usia harapan hidup bagi kemakmuran Kerajaan Majapahit sudah musnah secara total.

Data tekstual yang tercantum dalam Babad Tanah Jawi menyatakan, bahwa Ki Kebokenongo yang sudah masuk Islam itu sangat taat pada peraturan agama dan sudah mendirikan jemaat di Pengging. Ki Kebokenongo berguru kepada Pangeran Sitijenar. Kawannya berguru ada tiga orang, yaitu Ki Ageng Tingkir, Ki Ageng Ngerang, dan Ki Ageng Butuh. Empat sejawat tersebut sudah bersatu menjadi saudara atas kehendak Pangeran Sitijenar (Sudibjo, 1980: 48-50).

Seiring dengan itu, data tekstual yang tercantum dalam Babad Jaka Tingkir (Babad Pajang) menyatakan, bahwa aktivitas pemerintahan di Negara Pengging di bawah kekuasaan Raden Kebokenongo, yang kemudian terkenal dengan nama Ki Ageng Pengging didukung oleh tigaribu prajurit Pengging-Pajang yang selalu taat mengikuti jejak langkahnya. Di samping itu juga diikuti oleh tidak lebih dari empatratus pengikutnya yang setia selalu di dekat Ki Ageng Pengging. Keadaan masyarakat di Pengging dalam kehidupan sehari-hari, kecuali beribadah setelah selesai bersembahyang mercka juga rajin ke sawah dan ke ladang (Moeljonosastronaryatmo, 1981:71-73). Selanjutnya dinyatakan juga, bahwa Ki Ageng Pengging adalah koordinator bagi sahabat-sahabatnya seperguruan yang berjumlah empatpuluh orang di pesantren yang dipimpin oleh Syaikh Sitijenar. Segala ilmu yang dimiliki oleh Syaikh Sitijenar tertumpah pada Ki Ageng Pengging. Sahabat-sahabat Ki Ageng Pengging yang berjumlah empatpuluh orang yang ikut berguru pada Syaikh Sitijenar yaitu Ki Gede Banyubiru, Ki Gede Getas Jati, Ki Gede Balak, Ki Gede Butuh, Ki Gede Ngerang, Ki Gede Ngambat, Ki Gede Karangwaru, Ki Gede Babadan, Ki Gede Wanantara, Ki Gede Majasta, Ki Gede Tambakbaya, Ki Gede Bakilan, Ki Gede Tembalang, Ki Gede Karanggayam, Ki Gede Selandaka, Ki Gede Purwasada, Ki Gede Kebokangan, Ki Gede Kenalas, Ki Gede Waturante, Ki Gede Taruntun, Ki Gede Purna, Ki Gede Wanasaba, Ki Gede Kare, Ki Gede Gegulu, Ki Gede Candi di Gunung Pragota, Ki Gede Adibya, Ki Gede Karurungan, Ki Gede Jatingalih, Ki Gede Wanadadi, Ki Gede Tambangan, Ki Gede Ngampuhan, Ki Gede Bangsri Panengah. Keempatpuluh sahabat seilmu dan seperguruan tadi, mengaku saudara dengan $\mathrm{Ki}$ Ageng Pengging. Semakin kokoh dan akrab persahabatannya, antara Pengging, dan daerah-daerah yang dikuasai oleh sahabat-sahabatnya itu. (Moeljonosastronaryatmo, 1981: 75).

Dari pernyataan-pernyataan data tekstual yang tercantum dalam Babad Demak I, Babad Tanah Jawi, dan Babad Jaka Tingkir (Babad Pajang) tersebut di atas, dapat diasumsikan bahwa Raden Kebokenongo (Ki Ageng Pengging) adalah pemegang 
kekuasaan eksekutif dalam pemerintahan negara Pengging. Bentuk pemerintahan yang dianut di negara Pengging di bawah kepemimpinan Raden Kebokenongo adalah aristokrasi, karena Raden Kebokenongo berasal dari keluarga bangsawan keturunan Prabu Brawijaya raja Majapahit. Jabatan dan fungsi gelar Syaikh Akbar yang tersirat dalam epitap kuburan Ki Ageng Kebokenongo di Situs Pengging adalah dijabat oleh Ki Ageng Pengging seperti yang tercantum dalam naskah Babad Jaka Tingkir (Babad Pajang), demikian juga jabatan wali dijabat oleh tiga orang sahabat akrabnya, yaitu: Ki Ageng Tingkir, Ki Ageng Butuh, dan Ki Ageng Ngerang. Jabatan ulama dipegang oleh empatpuluh orang sahabat Ki Ageng Pengging yang seilmu dan seperguruan dalam pesantren yang dipimpin oleh Syaikh Sitijenar. Penobatan dan pengangkatan selaku wali, ulama dan syaikh akbar di Negara Pengging terjadi pada tahun $856 \mathrm{H}$ (tahun $1452 \mathrm{M})$ yang diabadikan pada epitap kuburan Ki Ageng Kebokenongo di Situs Pengging dilakukan oleh Syaikh Sitijenar.

\section{Kesimpulan}

Dari hasil pembahasan tentang makna epitap kuburan Ki Ageng Kebokenongo di Situs Pengging dalam manfaat ilmu pemerintahan,kiranya dapat disimpulkan secara tentative, bahwa proses terbentuknya lembaga dan organisasi pemerintahan di Negara Pengging terjadi sekitar tahun $1452 \mathrm{M}$ dapat dirunut sebagai berikut :

1. Sekitar tahun $1353 \mathrm{M}$ secara yuridis formal Pengging merupakan salah satu bentuk, lembaga dan organisasi pemerintahan desa di bawah kekuasaan pemerintahan Kerajaan Majapahit.

2. Dalam menyebarluaskan agama Islam, Syaikh Sitijenar sangat konsekuen dan konsisten dalam mengikuti suri teladan yang sudah digariskan oleh Nabi Muhammad SAW dalam Al Qur'an dan Al Hadits. Syaikh Sitijenar dalam melaksanakan dakwah Islamiyah dibantu oleh empat orang sahabat karibnya, yaitu: Ki Ageng Pengging (Ki Ageng Kebokenongo), Ki Ageng Tingkir, Ki Ageng Butuh, dan Ki Ageng Ngerang. Di antara empat sahabat ilmu dan seperguruan yang diangkat dan dinobatkan sebagai Syaikh Akbar di negara Pengging pada tahun $856 \mathrm{H}$ (tahun $1452 \mathrm{M}$ ) oleh Syaikh Sitijenar adalah Ki Ageng Pengging (Ki Ageng Kebokenongo). Sedangkan tiga sahabat seilmu dan seperguruannya, seperti: Ki Ageng Tingkir, Ki Ageng Butuh, dan Ki Ageng Ngerang masing-masing memangku jabatan wali di negara Pengging. Selanjutnya empatpuluh orang sahabat scilmu dan seperguruan di pesantren yang dipimpin oleh Syaikh Sitijenar itu masing-masing menjabat selaku seorang alim ulama di daerahnya.

3. Struktur lembaga dan organisasi pemerintahan di negara Pengging pada tahun $1452 \mathrm{M}$ dapat dirunut secara vertikal dari bawah ke atas dengan susunan lembaga 
-dan organisasi, yaitu:

a. Ulama, selaku pelaksana program operasional (eksekutif)

b. Wali. selaku perencana program operasional (legislatif).

c. Syaikh Akbar, selaku pemegang jabatan peradilan tertinggi di negara Pengging (yudikatif)

Bentuk lembaga dan organisasi pemerintahan di Negara Pengging sedikit ada kemiripannya dengan konsepsi Trias politika.

\section{KEPUSTAKAAN}

Abdul Choliq Nawawi, 1990. Kesinambungan Sosial Budaya Hindu-Islam di Wilayah Pengging. Skripsi, Jurusan Arkeologi, Fakultas Sastra, Universitas Gadjah Mada, Yogyakarta.

Anonim, 1995. Buku Pedoman Pelaksanaan Penelitian Arkeologi, disusun oleh: Panitia Khusus, terbitan Balai Arkeologi Yogyakarta.

Bayu Suryaningrat, 1980. Mengenal 1lmu Pemerintahan, terbitan: Aksara Baru, Jakarta.

Tanudirjo, D. A. (1994). Epigrafi Indonesia Dalam Kerangka Pikir Pasca - Modernisme. Berkala Arkeologi, 14(2), 10-16. https://doi.org/10.30883/jba.v14i2.634

Dwi Purwoko. 1990, Ensiklopedi Nasional Indonesia, Jilid (?), terbitan: PT. Cipta Adi Pustaka. Jakarta.

Enny Mulyantari, 1988, Pengalih Aksara "Babad Majapahit-Pajang", Yogyakarta.

Graaf, H.J., et.al., 1984. Chinese Moslems In.Java, In the 15th And 16th Centuries, terbitan: North Melbourne, Monash University Printed by Ruskin Press.

Hasan Djafar, 1978. Girindrawardhana Beberapa Masalah Majapahit Akhir, terbitan: Yayasan Dana Pendidikan Buddhis Nalanda, Jakarta.

Hassan Shadily, 1984. Ensiklopedi Indonesia, Jilid 6, terbitan: Buku lchtiar Baru - Van Hoeve, Jakarta. 
Lasiyo. et.al.. I 985. Pancasila (Pendekatan Secara Kefilsafatan), terbitan: Liberty, Yogyakarta.

Lien Dwiari Ratnawati, 1988. Peranan Sawah di Majapahit, Makalah, Trowulan: Seminar Analisis Hasil Penelitian Arkeologi, 7-11 Nopember 1988.

Moeljonosastronaryatmo, 1981. Babad Jaka Tingkir (Babad Pajang), terbitan: Proyek Penerbitan Buku Sastra Indonesia dan Daerah, Depdikbud, Jakarta.

Philips. C.H .. 1963. Handbook of Oriental History, terbitan: Offices of Royal Historical Society. London.

Pratomo, Mr., 1954. Petundjuk Tata Negara dan Tata Hukum Indonesia, Jilid 2, terbitan: S. King, Bandung.

Slametmulyana. 1979. Nagarakertagama dan Tafsir Sejarahnya, terbitan: Bhratara, Jakarta.

Slametriyadi. et.al.. 1981. Babad Demak I, terbitan: Proyek Penerbitan Buku Sastra Indonesia dan Daerah, Depdikbud, Jakarta.

Sudibjo, Z.H .. 1980. Babad Tanah Jawi, terbitan: Proyek Penerbitan Buku Sastra Indonesia dan Daerah, Depdikbud, Jakarta.

Zoetmulder. P.J., 1982. Old Javanese-English Dictionary, Jilid I, terbitan: Weltevreden. sGravenhage- Nijhoff. 